\title{
Iberian Jewish identities after 1492
}

\author{
Marianna D. Birnbaum
}

Original scientific paper

UDK 26-054.73(46)“654"

\begin{abstract}
The author investigates the types of Iberian Jewish and "converso" identities that emerged and evolved during the century that followed the Edict of 1492. Based on their life choices, the author discusses the fates of those who converted and stayed on the Peninsula, of those who, as New Christians, tried their luck elsewhere but remained secret Jews, and of those who returned to Judaism and shared the fate of their co-religionists in Europe and, finally, of those who migrated to the Ottoman Empire where they could enjoy more freedom and greater prosperity than in Christian Europe.
\end{abstract}

Keywords: Jewish refugees, Mendes/Nasi

Whereas in Antiquity and in the early Middle-Ages, the notion of exile meant the expulsion of Jews from their ancient homeland after the destruction of the Second Temple, by the sixteenth century, golah (exile) came to signify their forced separation from the Iberian Peninsula and their living in Diaspora communities (Koryakina 2015: 75-84). In my paper, I shall identify five distinct groups, and their activities, as aspects of the Sephardic (i.e. Iberian) Jewish identity, culled from documents and other sources relating to their lives and careers during the sixteenth and seventeenth centuries.

The first group consists of Jews who converted either in 1492 in Spain, or in successive waves between 1391 and 1492, and in a single act of forced baptism in 1479, in Portugal, in order to avoid expulsion from their homeland. Many of them were "anusim" (i.e. forcibly converted), but there was a sizeable part of the Jewish population, especially the succeeding generations, for whom their new 
religion meant not just social and political but also a spiritual solution for their lives. Many of those conversos, or New Christians, gained successful positions or participated in lucrative enterprises (import-export, banking, arms sales) that even took them to foreign countries (England, the Netherlands, the Italian citystates, etc.) where they conducted their business as Christians. ${ }^{1}$ Members of that group became sincere practicing Catholics. Of their descendants, some are only now beginning to discover their Jewish roots. According to a widely publicized study that appeared in the American Journal of Human Genetics (December, 2008), 19.8 percent of modern Spaniards (and Portuguese) have DNA reflecting Sephardic Jewish ancestry (compared to 10.6 percent having DNA reflecting North African ancestors).

Since I have written extensively about the Mendes/Nasi family, who can supply examples for each aspect of my contentions, I shall use them, and some of their friends and contemporaries, to illustrate my thesis (Birnbaum 2003, Wilke 2015: 117-134).

The Mendes/Nasi family (merchants and bankers) first decided to move from Spain to Portugal rather than to convert, but when they were forced to make the same choice in 1479, they became Christian in order to remain in the kingdom. Subsequently, members of the family became successful businessmen and bankers, creating a business network that included several royal courts. One member, Diogo Mendes, established a filiale in Antwerp to which, after the death of his brother Francisco, the latter's widow, Beatriz de Luna moved with her family. ${ }^{2}$ Diogo married Brianda, Beatriz's younger sister, in the Antwerp cathedral, accompanied by great pomp and circumstance. The family conducted their business as Christians. João (Joseph), and Bernardo, Beatriz's nephews, attended university in the company of Prince Maximilian, while Charles V and his sister Marie d'Hongrie (the Regent of the Low Countries) wanted to pick a husband who belonged to the royal family for Reyna, her daughter. ${ }^{3}$ It is fair to

\footnotetext{
${ }^{1}$ I am not using the often -applied term Marrano, because no converted Jew used it as a self-description. Marrano was a slur used against Jews, sometimes even by conversos who tried to discredit a person as a "fake-Christian".

2 Beatriz (Beatrix) de Luna (or Gracia Mendes Nasi, 1510-1569) became the family's matriarch. They probably moved because Gracia wanted to save the family fortune, which was threatened by the increasing power of the Inquisition.

${ }^{3}$ Maximilian II (1520-1576), Holy Roman Emperor; Charles V (1500-1558), Holy Roman Emperor; Marie d'Hongrie (aka Mary of Hungary or Mary of Austria, 1505-1558, Regent of the Low Countries), sister of Charles V.
} 
claim that at this point in her life, at the very least Brianda, Beatriz's younger sister, was a faithful Christian.

"Secret Jews" (crypto-Jews) form the second part of the same group: forcibly converted Jews who, while practitioners of their new faith in public, remained Jews "in petto," observed the Sabbath secretly in their homes and taught their children to do the same. Since "Judaizing" was a capital crime and the accused often had to endure brutal questio (torture), secret Jews were probably far fewer in number than what the Inquisition or later Jewish historians liked to claim. ${ }^{4}$

In order to avoid the unwanted marriage I mentioned above, Beatriz secretly moved with her sister and two young daughters (one hers, the other Brianda's) to Italy, first to Venice (1545) then to Ferrara (1458), finally leaving Italy from Venice. In Ferrara, they declared themselves Jews and Gracia became a mentor to Jewish scholars and artists. The famous Ferrara Bible of 1553 (printed by Abraham Usque, possibly a Portuguese "secret Jew" who was known in Italy by his Christian name, Duarte Piñel) appeared in two versions. One was dedicated to Duke Ercole d'Este, and the other, a "Jewish printing", to Beatriz, who called herself Gracia Mendes, or Gracia Nasi in Ferrara (Birnbaum 2003: 56-57). ${ }^{5}$ Charles $\mathrm{V}$ wanted to force her to return to Anwerp and declare them all heretics (including the deceased Diogo). The emperor's effort was prompted mainly by the desire to seize the family's vast fortune, which included Diogo's inheritance. If a deceased person was declared a heretic, his body was not just removed from the sacred burial grounds but his entire fortune reverted to the Crown. At the same time, Joseph continued to do business with Charles $V$ and Francis $I^{6}$ as a Christian until several years later, when he too appeared in Ferrara and joined the family, albeit still as a Christian.

\footnotetext{
${ }^{4}$ It is beyond the scope of this paper to cite the plethora of literature regarding the Inquisition.

5 The Ferrara Bible was published on March 1, 1553. Both editions received ducal permission and the "fiat" from the Inquisition. For a new edition, see Biblia de Ferrara (edition y Prólogo de Moshe Lazar) (Madrid: Fundación José Atonio de Castro, 1996). The still ongoing scholarly debate regarding the identity of the printer cannot be addressed in this connection.

${ }^{6}$ Francis I of France (1494-1547).
} 
Interestingly, while living as a Jew in Ferrara, Gracia engaged in trade as a Christian in Venice and in Dubrovnik/Ragusa. In those dealings she used the name Beatrix de Luna. ${ }^{7}$ Thus, for a variety of reasons, the family remained crypto-Jews for many years after their emigration from the Iberian world.

Since such conversions were forced, in the eyes of the Inquisition, the entire Iberian Peninsula was rife with heretics and Judaizers who had to be found and punished by the frequent autos-da-fe. The existence of conversos when living or travelling in Christian countries was equally hazardous, because the Inquisition's agents spied on them wherever they stayed; searched them out in Venice or Ferrara in order to face the accusation of "Judaizing". Therefore, it is reasonable to contend that there were also 'imagined' Jews, whose alleged activities reflected mainly the mindset of the inquisitors and their henchmen (hundreds of persons are known based on the charges against them: cold chimneys on the Sabbath, refusal to eat pork, crucifying cats, defacing the image of the Virgin, etc.). This sophisticated data gathering, as revealed by the records of the hearings, testify to the limitless imagination of the accusers. I submit that in the sixteenth century, "the eye of the beholder" created the third type of Jew, or a person of Jewish origin. A good (secular) example is the English theatre: Shakespeare and Marlowe were not supposed to have seen a live Jew in their midst (Birnbaum 2015: 217-229). Thus, in a reverse of the causal relationship between fact and fiction, the Jew on the Renaissance stage preceded the Jew in the street.

When the Venetian Inquisition started to investigate the Mendes sisters mostly for financial reasons, the records show that the Office's aim was to prove that they (secretly) followed kosher dietary restrictions, did not venerate Christian saints, etc. Their servants and brokers were questioned and threatened, some of them secret Jews (as it turned out), some Christians, who had accompanied the sisters from the Low Countries. Whereas by 1556 Gracia was safely in the Ottoman Empire, Brianda endured lengthy hearings. We have the records of the Inquisition regarding the questioning of Tristan (Tristão) da Costa, a broker (and perhaps a lover of Brianda) (Birnbaum 2003: 49-52). He admitted that he was a secret Jew but insisted that Brianda had been a genuinely faithful

7 Material preserved in the Historical Archives of Dubrovnik includes the resolutions of the Senate regarding her business dealings with the city-state. Gracia's name appears as Beatrix di Luna in the Compendium under "Lettere e Commissioni " (Lettere di Levante). 
Christian. He claimed that he must have been denounced by the Molino family, competitors of Gracia on the commodities market (mainly sugar and pepper). Finally, Brianda was believed to be a true Christian, and was set free, receiving safe conduct. However, a several days later, she returned to her inquisitors, declared herself a Jew, and voiced her desire to join Gracia in Constantinople.

Tristan da Costa's case is another example of secret Jews using several names. In Ferrara, Costa used his father's name and was called Isaac Habibi. Secret Jews lived a life of forced duplicity: the Jewish garb imposed upon them by law concealed the real person, whereas the Christian exterior often concealed a trembling Jew who could have been denounced by any person of ill will. (The word "passing", used almost exclusively for blacks appearing as whites in modern society, should be reconsidered for this broader application.)

Iberian Jews who refused to convert and succeeded in leaving the Peninsula for places that tolerated them, form the fourth kind of identity: there were many Sephardic Jews who departed to the various kingdoms or principalities of Italy, where they joined their co-religionists in ghettoes (like in Venice, Rome or the Republic of Ragusa), and shared the lives of the local Jews, accepting the stringent restrictions that had been placed upon them (Bonfil 1994). ${ }^{8}$

It is known that despite their discrimination, many Jews lived comfortably in both Venice and in Rome. (This is not the place to discuss the role of ghettos although they segregated Jews from the rest of the society, they also allowed them permanent residency.)

Those who could escape to the Netherlands had it easier thanks to a higher level of tolerance that provided Jews and conversos with a safer life: The late sixteenth and early seventeenth centuries saw their rise. There was a separate Hebrew school created for the Portuguese Jews in Amsterdam (Nosa Academia), meant to 're-school' the "Judaizers," i.e. those conversos who sought to return to Rabbinical Judaism. Kosher butchers set up shop in the Jewish section, and the local Jews gained royal permission to consecrate a Jewish cemetery (Beth Haim on the Amstel) for the Spanish and Portuguese communities. The new arrivals held tight to their Iberian identities. The complexity of the notion "exile" is illuminated by a statement of Yom Tov ben

\footnotetext{
8 The many restrictions notwithstanding, in Venice and in Rome, Jews participated in the local economy, in banking and as merchants.
} 
Moses Tzahalon (d. 1638) in which he referred to "the holy community of the Spanish exile which is in Jerusalem" (Koryakian 2015: 115). ${ }^{9}$

One of those refugees to the Netherlands was Menasseh ben Israel, who was born in $1604 .{ }^{10} \mathrm{~A}$ year after Menasseh's birth, the family left Portugal due to the Inquisition. They arrived in Amsterdam in 1610, during a truce in the religious war mediated by France and England at The Hague. Menasseh rose to eminence as a rabbi, author, philosopher and printer. His best-known work, El Conciliador, published in 1632, was an attempt to reconcile the apparent discrepancies in various parts of the Old Testament. He was also one of the teachers (or at least mentor) of Baruch Spinoza. ${ }^{11}$ Since he was unable to provide for his wife and family in Amsterdam, in 1638 he tried to settle in Brazil as a rabbi, but he was not nominated. Later he undertook the cause of Jews who wanted permission to resettle in England, whence they had been banished by King Edward I in 1290. Oliver Cromwell ${ }^{12}$ was sympathetic to the Jewish cause, partly because of his tolerant leanings, but chiefly because he foresaw the importance of Jewish merchants to English commerce. The English gave the Jews full rights in the colony of Suriname, which they had controlled since $1650 .{ }^{13}$

In 1655, Menasseh arrived in London (during his absence from the Netherlands, the Amsterdam rabbis excommunicated Baruch Spinoza). In London, Menasseh published his Humble Addresses to the Lord Protector resulting in Cromwell's summons to the Whitehall Conference in December of the same year. Its result was a declaration stating that, "there was no law which forbade the Jews' return to England". Thereafter, although no legislation regulated the status of the Jews, the door was opened to their gradual return. ${ }^{14}$

9 Thus turning around the phrase, "the exiles of Jerusalem who are in Sefarad" [Abdias 1:20]).

10 Here I have expanded the time-frame to include (albeit briefly) the career of Menasseh ben Israel (1604-1657), because it illustrates the special situation of the Jews residing in the Low Countries and connects them to England.

${ }^{11}$ Baruch Spinoza (1632-1677), Dutch philosopher of Portuguese (Sephardic) origin.

12 Oliver Cromwell (1599-1658) then Lord Protector of the Commonwealth of England.

13 Dutch traders began visiting the region of today's Suriname in large numbers only after it had been acquired by the Dutch in a war against England. Soon approximately one thousand white men - among them Jews from Brazil - owned plantations, maintained by Indians and African slaves.

14 Jews were officially permitted to resettle in England in 1753 when The Jewish Naturalization Act was passed. 
Soon after Menasseh left London, Cromwell granted him a pension, but he died before enjoying it. ${ }^{15} \mathrm{His}$ tomb is in Amsterdam's Beth Haim on the Amstel.

Those who fared best were the Iberian Jews who migrated to the Ottoman Empire, where they were granted a much higher degree of personal and religious freedom than anywhere in Christian Europe. Although they had dhimmi status (which they shared with Christians and other religious minorities), Iberian Jews flourished wherever the Porte ruled. The "golden century" of Jews was closely tied to that of the Ottoman Empire (Birnbaum 2003: 82-93). ${ }^{16}$

However, by the time Iberian refugees reached that haven, many of the conversos (or as the benevolent Church preferred to call them, "New Christians") had been practicing their Catholic faith for generations and were, by and large ignorant of Jewish laws and practices. They were what could be called "New Jews", who had to adjust to and learn from the existing Jewish population of the Empire. The council of rabbis (especially in Salonika) who governed the spiritual life of Jews in their galut and golah had the formidable task of defining "who was a Jew". In their Responsa (rulings), the rabbis addressed a plethora of issues, including the concept of re-conversion, circumcision, inheritance, loans and interests (for example, from a non-Jew), Jewish divorce (from a converso or a Christian), the rights and obligations of a Jewish widow and so forth (Birnbaum 2003: 89-90).

Here again, examples from the Mendes family are at hand. In Venice, Joseph was accused of and sentenced to death (in absentia) for kidnapping Brianda's daughter, Gracia la Chica, and marrying her against the will of the family. This must have been a manoeuvre designed to save the family's fortune because in Ferrara in 1556, this same daughter married Bernardo, the younger brother of Joseph in a Jewish wedding and migrated with him to the Ottoman Empire. Their marriage was accepted as valid there. Thus, since it was Christian, Joseph's marriage to the same Gracia La Chica must have been annulled by the rabbis. In Constantinople, Joseph had himself circumcised, openly returned to

15 It is interesting to note that an earlier Cromwell, the Privy Counsellor of Henry VIII, granted the Mendes widow (and her household) safe conduct through England on their way to Antwerp - documents which they ultimately did not have to use.

16 European Christians visiting the Porte were shocked to learn that Jews living in the Empire enjoyed the same freedoms as Christians. 
Judaism and married Reyna, Gracia's daughter. In 1566, Süleyman appointed Josef, a practicing Jew, prince of Naxos and the Cycladic Islands. ${ }^{17}$

Gracia Mendes, who venerated rabbis and scholarship, founded a Talmudic school in Tiberias and supported a Midrash school for the study of rabbinical literature (all using income derived from various properties in Salonika). Joseph owned a large collection of books and manuscripts and patronized scholars and artists, playing the role of a European aristocrat (Gerlach 1674: 89-90). ${ }^{18}$ They always considered themselves Portuguese, dressed according to Spanish/Portuguese fashion, supported and attended the Portuguese synagogue and continued assisting Iberian newcomers settle in the Empire.

The life paths of Gracia and Joseph, reminiscent of a soap opera, testify to the great variety of lifestyles and identities that the Iberian Jews had assumed after their expulsion from the Peninsula. Since the Mendes/Nasi family was fabulously wealthy, their pursuits do not offer more than a glimpse into the lives of their less fortunate co-religionists. Even so, their spectacular careers, full of stellar achievements, are also full of ambiguity. The frequent displacements of the Mendes/Nasi family were not so different from the rest of the Iberian refugees. While retaining their love for their Iberian heritage and traditions, they all tried to find and establish new homes and new roots for themselves, facing unwanted adventures, adversity and much insecurity.

17 In 1561, the family received a concession from the sultan to rebuild the town Safed (today Tsfat) and resettle it with Jews. Roth referred to Tiberias.

18 Stephan Gerlach, a German serving in the Imperial Embassy in Constantinople, described a feast held at the Nasi residence amidst priceless French furniture and European art. 
126

\section{Bibliography}

BIRNBAUM 2003

Marianna D. Birnbaum, The Long Journey of Gracia Mendes, BudapestNew York 2003.

BIRNBAUM 2015

Marianna D. Birnbaum, "Christopher Marlowe and the Jews of Malta," in: Expulsion and Diaspora Formation: Religious and Ethnic Identities in Flux from Antiquity to the Seventeenth Century (ed. John Tolan), Turnhout 2015, 217-229.

BONFIL 1994

Roberto Bonfil, Jewish Life in Renaissance Italy, Berkeley 1994.

\section{GERLACH 1674}

Stephan Gerlach, Tage-Buch, Frankfurt-am-Main 1674.

\section{KORYAKINA 2015}

Nadezda Koryakina, "'The first exile is ours': the term golah and galut in medieval and early modern Jewish responsa," in: Expulsion and Diaspora Formation: Religious and Ethnic Identities in Flux from Antiquity to the Seventeenth Century (ed. John Tolan), Turnhout 2015, 75-84.

ROTH 1947

Cecil Roth, The House of Nasi, Duke of Naxos, Philadelphia 1947.

WILKE 2015

Carsten L. Wilke, "Losing Spain, securing Zion: allegory and mental adaption to exile among refugees of the Iberian inquisitions," in: Expulsion and Diaspora Formation: Religious and Ethnic Identities in Flux from Antiquity to the Seventeenth Century (ed. John Tolan), Turnhout 2015, 117-134. 